\title{
Rugian Slavic God Sventovit - One More Time
}

\section{= Roman Zaroff}

This paper critically analyses and discusses two recent re-interpretations of the name of the Slavic god known as Sventovit. This deity was worshipped on Rügen Island, on Wittow Peninsula, at a locality called Arkona. The temple of Sventovit, with his four-headed statue, stood there on the cliff there in the Middle Ages until its destruction by the Danes in 1168/9. The paper explores an article by Michał Łuczyński published in the Polish journal Ling Varia in 2015, and a chapter on Sventovit in the book by Judith Kalik and Alexander Uchitel, titled Slavic Gods and Heroes, which was published by Routledge in 2018, in the USA and UK. In his work, Łuczyński postulated that root-stem -vit in the name of a deity is, in fact, a suffix -ovit implying its attributive character. The paper argues for a widely accepted explanation that root-stem -vit derives from the Slavic vitędzb, denoting warrior, hero, freeman, lord, master or ruler. In their book, Kalik and Uchitel argued that the name "Sventovit" was a corrupted form of the name of the Christian Saint Vitus. This article challenges this notion, arguing that the deity's name Sventovit has nothing to do with Saint Vitus.

KEYWORDS: Sventovit, Slavic mythology, religion, Polabians, Rugen Island

The discourse concerning the name and etymology of the Slavic pre-Christian deity Sventovit, worshipped in Middle Ages on Rügen Island at Arkona, remains active. It is encouraging that the history of the Polabian Slavs and Slavic pre-Christian beliefs are still of interest among many contemporary mediaeval scholars. In recent times, I have encountered two new interpretations concerning the above topic. There was an article by Polish scholar Michał Łuczyński "Staropołabskie teonimy *Svętovitъ, *Jarovitъ, *Rujevitb, *Borovitb: deadiectiva czy composita?”, published in 2015. Another publication was an interpretation by Judith Kalik and Alexander Uchitel in the book titled Slavic Gods and Heroes, which appeared in 2018. The Slavic deity Sventovit, *Svętovitb in Slavic, was recorded only in Latin transcripts and had various spelling according to the source. This should not be a surprise as none of the chroniclers and annalists were native Slavic speakers. Thus, the name passed on were phonetic recordings of an alien name. They have been recorded in various ways, such as Suantovitu (Saxo, XIV.39), Suantouith, Suantuitho (Saxo, XIV.39), Szuentevi, Suantevit, Zuantevith (Helmold I.52; II.108(12)), 
and Svanteviz (Knytlinga, 122). There is a consensus among most of the scholars that the original Slavonic name of this deity was *Svętovitz (Łuczyński 2015: 110). To be clear, the anglicized form "Sventovit" will be used in this paper.

\section{ROMAN ZAROFF'S INTERPRETATION}

In my article "The Origins of Sventovit of Rügen", published in 2002, in the journal Studia Mythologica Slavica, I presented my interpretation and provided my explanation for the etymology of Sventovit's name. Briefly, it had been postulated that the name is dithematic and comprises two elements to be called root-stem in this work. The first de-

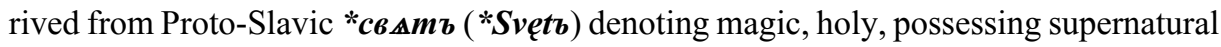
properties and also might and power. Hence, in the case of Sventovit, it denotes might, strength, and power (Brückner 1985A: 537; Boryś 2006: 623). Over the course of the time, under Christian influence, the term changed its meaning and became synonymous with the noun "saint". The second element, the suffix -vitz, was explained as deriving from an Old Slavonic noun *vitęzb - meaning a warrior, freeman, lord and/or master. In this context, the etymology of the name Sventovit was postulated to mean a "Strong, Mighty, Lord" (Zaroff 2002: 3). The above etymology and meaning of the name Sventovit has long been accepted by the overwhelming majority of scholars, starting with Josef Dobrovsky in the early $19^{\text {th }}$ century (Niederle: 1916 142n) and by such scholars as Lubor Niederle (Niederle 1916: 142n), Stanisław Urbańczyk (S. Urbańczyk 1947: 34-35), Rajko Nahtigal (Nahtigal 1956: 1), Leszek Moszyński (Moszyński 1975: 591), Jerzy Strzelczyk (Strzelczyk 1998: 210), Aleksander Gieysztor (Gieysztor 1982: 90-91), Eric Christianson (Christiansen 1984: 836(n477)), Ken Dowden (Dowden 2000: 215), Stanisław Rosik (Rosik 2000: 128) and Andrzej Szyjewski (Szyjewski 2003: 116) to name but few. Although, as it happens, it is common in the fields of history, linguistics, and etymology, consensus on this issue is not shared by all scholars. The issue that recently reappeared will be addressed and discussed in detail in the course of this paper.

\section{MICHAŁ ŁUCZYŃSKI’S - A NEW LINGUISTIC INTERPRETATION}

As aforementioned, Slavic names are usually dithematic with two meaningful root-stems. In the case of Sventovit, Łuczyński proposed a new etymology for the name of this god. He did not challenge the notion that root-stem svętz, meaning strong, mighty, powerful, magic, holy, possessing supernatural properties (Luczyński 2015: 110), and that the term acquired its current meaning of something saintly, holy, which became synonymous with saint and sainthood only in Christian times (Brückner 1985A: 537). It should also be noted that a number of Russian scholars who followed the Tartu-Moscow Semiotic School, such as Oleg Trubachev, Vladimir Toporov and Boris Rybakov derived root-stem svętı from Slavic term denoting light and/or brightness (Trubachev 2003: 418-420; Toporov 2014: 339; Rybakov 1981: 300). 
However, Łuczyński argued that in the name Sventovit's two root-stems are not svętbo-vitb, but rather svętb-ovitb. Therefore, he introduced a suffix -ovit instead. An alleged suffix -ovit is supposed to be an adjective serving an attributive and/or possessive function in the name. On its own, the linguistic argument about the suffix -ovit as presented by Łuczyński is a well-researched and scholarly presented analysis. For instance, in the Polish language, jad means poison and the verb jadowity means poisonous, or smak - a taste, and smakowity, which means tasty. He concluded that the suffix -ovit meant "one that possesses' a lot of, one who is full of". In this interpretation, the name Sventovit would mean "one that possesses a lot of power, strength" ((Łuczyński 2015: 115). It should be noted that previously mentioned followers of the Tartu-Moscow Semiotic School, such as Trubachev, derived root-stem vitb, from an Indo-European *ueik-t or *uik-t denoting vital force, and Rybakov explained -vitb as joy, happiness or abundance (Rybakov, 1981: 300). Lubor Niederle has seen the element vit as of Slavonic origin, although he perceived it as unexplained (Niederle 1916: 142). To best of my knowledge, only the Russian Nataliya Ganina follows Trubachev (Trubachev 2004: 428-429) in support of Łuczyński's claim that the suffix -ovit, in the name of Sventovit is a substantive adjective (Ganina 2015: 71).

Unfortunately, introducing the suffix -ovitb as a part of Sventovit and to other similar names is not very convincing. Above all, Łuczyński's impressive linguistic exercise does not explain the origins of common Slavic names beginning with element vitb-. To name only a few historical figures, we have Vitoslav, and its variants appear in Czech as Vitězslav, and in Croatian and Slovene as Vitislav. Just to mention some historical figures, we have Vitoslav (Vitislan, Vitisla), a Bohemian duke mentioned in the $9^{\text {th }}$ century (Annales Fuldenses, Years 872; 895). In Polish historical sources, a certain Witosław (Vitozlaus) is mentioned in a document from 1193 issued by Pope Celestine III (Bull of Celestine III, Celestinus pp. III 1193 Apr. 8). Another Witosław (Vitoslaus) appears in a Privilege for the Benedictine monastery at Mogilno in 1143 issued by Mieszko III the Old (Mesco dux Polonie, 1103). There was a certain Witomir (Vithmarus) in another document from 1247 (Fr. Michael Abbas in Paradiso 1247).

As previously stated, Slavic names are dithematic but were also abbreviated, shortened, or used in a diminutive form. These applied not only to the common people but also were used in the case of the rulers. For instance, Prince Bolesław II of Świdnica was often referred to as "Bolko". This must have been a case of an Obodrite duke Witčan of the late $8^{\text {th }}$ century (ARF, 789; 795), whose name begins with the element vitb-. Similarly, a Polish document Ex commisso nobis known as the Bull of Gniezno issued by Pope Innocent II in 1136 mentions Witosza (Vitossa) and Witosz (Vitos) (Bull of Gniezno of 1136). Also, a deputy judge Witek (Vitec) appears at Gniezno in 1247 (Conradus dux Lanchicie, 1247). In the last three Polish examples, it could be argued that the names are Slavicized forms of the Latin name Vitus, derived from Saint Vitus (Sanctus Vitus), but it equally plausible that they are simply just abbreviations of Slavic dithematic names, such as Witosław, Witomir, Witomysł, or Vitodrag (Niederle 1916: 142). So, in all probability it is an old Serbian name Vitzko (Nahtigal 1956: 3). Therefore, this clearly indicates that element vit in personal names cannot be an attributive/possessive adjective (Kalik \& Uchitel 2018: 54), and existed on its own as a noun. 
Moreover, there a are plethora of place names across the entire Slavdom beginning with Vit, Wit or alike. To cite just a few examples, Polish Witomyśl (Vitomisl) mentioned in 1250 (DLW, Doc. 286, year 1250), is evidently a patronymic name. Another example, Witkowo (Vittovo) recorded in 1259 (DLW, Doc. 382, year 1259), or Vitačiv (Вїтачїв) in Ukraine (Wędzki 2008:686-687). Furthermore, an old Slavic settlement of Vityň (Vitin), a tribal centre of the Niditse (Pol. Nidzice) in East Germany (Ger. Witten) was mentioned in 961 (SSS, Vol. 6:504), or the Vitosha Mountains in Bulgaria, which are derived either from the personal name Vitoš or the word viteź-vit. Finally, the Łuczyński hypothesis does not explain the name of Wittow Peninsula on Rügen Island, where a Sventovit temple stood and where to these days small village called Witt exists.

In addition, the "o" in the name Svent-o-tovit is extremely unlikely to be a part of an alleged suffix -ovit. Examining other Slavonic names, it is abundantly clear that it is simply not so. It should be noted that, for example, the name Gněvomir comprises the root-stem gnĕvb - the wrath (Boryś 2006: 168) and mirb - meaning respect in this context. Hence the name follows a pattern Gnĕvo-mir, not a Gnĕv-omir. Similarly, Gostomysł is a combination of gostb - guest (Boryś 2006: 174), and myslb - a thought, thoughtful (Boryś 2006: 344 345), but within the name, it means "One that is well disposed to guest; a hospitable one". So, it is Gosto-mysł not Gost-omysł. There are a countless number of other Slavonic names showing the above pattern. Moreover, the personal names containing the element svętz- such Czech Svatopluk, Svatoslav or Polish Świętopełk, Świętobor, Świętosława or Eastern Slavic Svyatoslav (Святослав), or a mythical hero Svyatogor (Святогор) evidently show the same pattern. The pattern identified in the name's the element svętz- becomes svętъO-, where Svento-vit, rather than Svent-ovit fits perfectly.

Furthermore, let us examine the Southern Slavic name Ljudevit. It was the name of a Croatian ruler of Southern Pannonia, Duke Ljudevit of Passau, circa 810-823 (ARF, 818 ). The name contains the Proto-Slavic element $* l j u d b-$ meaning people. In the $9^{\text {th }}$ century, the people would be called ljud the Polish form ludzie. It has to be considered that, in mediaeval times, the naming of children was of utmost importance and carried significant meaning. Naming children was of a mystical or magic-like ritualized nature ceremony. They were often perceived as assuring their children future characteristics, virtues, prestige and status that they hoped they would possess.

As a consequence, it carried an important message of assurance for the future wellbeing and success of the child. This issue was comprehensively addressed by Bożena Hrynkiewicz-Adamskich in her article published in 2011 (Hrynkiewicz-Adamskich 2011: 177 196). In this context, it is much more convincing that together with the suffix -vitb as a lord, master, the name Ljudevit would have meant "The lord of the people", as an appropriate given name for a member of the ruling Croatian house, rather than meaning something else. Simply adding the suffix -vit would add to the name much more importance and prestige than an alleged attributive/possessive -evit proposed by Łuczyński.

As was postulated in my 2002 article, the element vitb is in Slavic names derived from an abbreviated form of Old Slavonic vitedzb $<*$ viteg b meaning warrior, hero, freeman, lord, master, ruler. It is a common Slavic noun; therefore, it must have proceeded the 
Slavic migration period of the $5^{\text {th }}$ to $7^{\text {th }}$ centuries C.E. It appears in Czech in the form of vitěz, a victor, in Lusatian Sorbian as witez or wičaz a hero. In the Polish language, witeź or wiciqdz, means a warrior, in Russian and Ukrainian витязь (witiaź) a warrior, Croatian vitte z, Slovene vitez, Bulgarian, Macedonian and in Serbian вumez (vitez) - all meaning a knight, warrior or concepts associated with warriors, bravery, lordship, master and power, winner or victor, or a member of the Slavic class of warriors (Vasmer 1986, ed: 322-323; Brückner: 1985A: 658-659; Gieysztor 1982: 90-91; Boryś 2006: 747). Hence, all Slavic variants are conceptually cognate. From Slavic languages, the term also entered Hungarian as vitéz and Romanian as viteaz, and denotes someone gallant or valiant (S. Urbańczyk 1975: 502). Such an interpretation has a wide consensus among scholars, including Aleksander Brückner (Brückner 1985B: 35), Stanisław Urbańczyk (S. Urbańczyk 1947: 34-35), Janisław Osięgłowski (Osięgłowski 1971: 136), Alexander Gieysztor (Gieysztor 1982: 90), Jerzy Strzelczyk (Strzelczyk 1998: 210), Eric Christiansen (Christiansen 1984: 836(n477)), Ken Dowden (Dowden 2000: 215), Stanisław Rosik (Rosik 2000: 128), or Andrzej Szyjewski (Szyjewski 2003: 116), to cite a few.

The origin of the term witiaź/vitędzb < *vitegb is not entirely clear. However, most authorities assume that it is a borrowing from Old East Germanic, likely a Gothic-related language, before the Slavic Migration Period. The term also appears in Baltic Old Prussian as witing, to denote native Prussians in military service of Teutonic Knights (Vasmer 1986, ed., Vol I: 322), reinforcing the notion of the early borrowing from the Eastern Germanic language. It should also be noted that in early Slavic borrowings from the Germanic sound "g" tended to change to "z" or "dz". This is demonstrated in the case of kuningaz, to kbnęzb denoting a prince or ruler (Gołąb 1992: 72), and in Old Slavonic

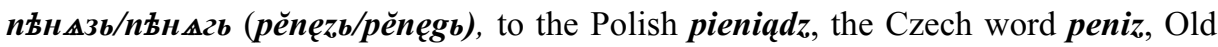
Russian пенязь (рёпјазь) for money or coin; and derived from an Old Lower German pfenning (Gołąb 1992: 381). All this implies that it originated from the term witing, or similar. Unfortunately, this is not attested in any written records. It is likely to be related to the Gothic witan - to keep watch, to guard (Skeat 1868: 273). A similar term is attested in Gothic by weihan/weigan, to fight (Skeat 1868: 267-268; Balg 1889: 540-541; Gołąb 1992: 381-382), or perhaps it shares the origin with later Old Icelandic hvitingr, meaning fair-haired, but also noble, distinguished (Vasmer 1986, ed., Vol I: 323). The term Viking, from Old Norse vikingr, acquired a meaning of sea-farer, pirate, and warrior in later times, may also had derived from this common Old Germanic term witting (S. Urbańczyk 1975: 502). The most plausible explanation is by Zbigniew Gołąb who proposed that witing was likely a term used by the earliest, pre-Gothic, East Germanic migrants, possibly the Germano-Celtic Bastarnae or Germanic Vandals, sometime between as early as the $3^{\text {rd }}$ to $1^{\text {st }}$ centuries BCE, and then entered Proto-Slavic and Proto-Baltic languages (Gołąb 1992: 382).

Moreover, the suffix -vitb denoting a lord or master is better suited to the unquestionable military aspects of Sventovit's cult, and other functions of agricultural, vegetative, harvest and prophetic abilities. In other words, in the henotheistic pantheon of the Slavs, Sventovit acquired a leading, if not a supreme role. It should be noted that, in many religions, higher or supreme gods are called "Lord". For instance, the name of the Zoroastrian god Ahura 
Mazda, who is a creator and sole deity, comprises of the word Ahura - mighty and/or lord, and Mazda - wisdom. Thus, the literal meaning of Ahura Mazda is "Wise Lord".

The postulated transonimization of an adjective into a proper noun by Łuczyński (Luczyński 2015: 111-112), appears to be merely a hypothesis and, in this case, lacks substantial evidence other than a long sequence of speculative arguments. Łuczyński argued that there is no clear evidence for the association of the suffix vitz with the noun witiaź, citing doubts expressed by Aleksander Brückner (Łuczyński 2015: 110-111). It needs to be acknowledged here that the linguistic and grammatical rules, laws and patterns are powerful and extremely useful tools in scholarly linguistic, philological, and etymological analysis and reconstruction. There is absolutely no doubt about it. However, linguistics is not mathematics, and there cannot be linguistic dogmas. Languages are living social phenomena, and unpredictable, unexpected, unexplainable changes may and do take place. Two simple cases can be presented here. A term for spider in all Slavic languages derives from the common Slavic pauk-like, from Old Slavonic pagkb, while in Polish it is pająk (Boryś 2006: 408), or another common Slavic word medvĕdb a bear, is niedźwied $z$ in Polish (Boryś 2006: 360). Both these instances and a multitude of other examples defy not only an explanation, but the change often does not follow any linguistic "rule". The linguistics can clearly describe the changes that occurred, but sometimes do not provide the answer as to "why".

To conclude this section, although some doubts remain and have to be acknowledged here, the presented argument and cumulative evidence clearly indicates that Łuczyński's hypothesis is not very convincing. Therefore, in the name of the Rugian Slavic deity Sventovit, there is no attributive or possessive suffix -ovitb, but there is a commonly accepted suffix -vitb. In all probability, it derives from the Slavonic term witiaź, which denotes a lord, master or someone in a position of authority, and it appeared in an abbreviated form in names.

\section{ORIGIN OF SVENTOVIT BY JUDITH KALIK AND ALEXANDER UCHITEL, FROM THE BOOK: SLAVIC GODS AND HEROES}

A recent book by two scholars, Judith Kalik and Alexander Uchitel, and titled Slavic Gods and Heroes that was published by Routledge in 2018 offers a controversial revision of Pre-Christian Slavic beliefs. A relevant part of the book for the purpose of this paper is a chapter on Sventovit. These scholars postulated that the name Sventovit derives from that of Saint Vitus. The authors claimed that the Ranove (Rani) nominally accepted Christianity in times of Otto I, who was a German king since 936 and Emperor from 962 until his death in 972. Supposedly, the Ranove needed the Empire's support against the Danish threat. Allegedly, not very long after that, the Ranove reverted to their pre-Christian beliefs and began to worship Saint Vitus in a corrupted form, that is, as a deity known as Sventovit (Kalik \& Uchitel 2018: 54).

At the beginning of the section on Sventovit, the authors cited Helmold of Bossau, who composed his Chronica Sclavorum sometime between 1163 and 1171, describing the 
events since the time of Charlemagne. According to Helmold, in the times of Louis II the Younger, Holy Roman Emperor 844-876, monks from the Abbey of Corvey underwent a mission to the Ranove of Rügen Island. Consequently, they were converted to Christianity, and an oratory devoted to Saint Vitus was established there. Shortly afterwards, the Ranove reverted to their pre-Christian beliefs and began to worship a misinterpreted Saint Vitus as Sventovit (Helmold I.6). Helmold repeats the story in a similar way in the Second Book of his chronicle, but this time places it in the time of Louis I the Pious, who was Charlemagne's son and Emperor from 814 to 840 (Helmold II.108). They have also cited a fragment from Gesta Danorum composed by a Danish chronicler Saxo Grammaticus. Saxo repeats Helmold's claim, but placed it in the times of Charlemagne's reign of 768 to 814 and their apostasy after his death (Saxo XIV.39). There is strong evidence that Saxo knew Helmold's chronicle (Christiansen 1984:704-705), and his notion about Saint Vitus' origin of Sventovit comes from that source. Saxo was a chaplain of the bishop of Roskilde, and he wrote his Gesta Danorum sometime after 1185. He died around 1204. The chronicle provides a vivid description of the pagan cult there, the temple of the god Sventovit at Arkona, and its destruction in 1168/69 (Saxo XIV.39). A relatively in-depth knowledge and understanding of the contemporary Baltic Slavs and their affairs is visible throughout the chronicle. His account about the pagan temple, idol, and ceremonies held at Arkona are regarded as most trustworthy. He either participated in the 1168/69 expedition or received information from the Danish bishop of Roskilde, Absalon, who led the expedition against the Ranove. The Ranove principality under Slavic prince Tetzlav (Pol. Ciesław) became a Danish tithe and ecclesiastically under Danish bishopric of Roskilde (Ellis 1978: 2; Słupecki 1994: 33). It should be also noted that church erected by Danes in Rügen Island at Altenkirchen, shortly after 1168/1169 was consecrated to Saint Mary not Saint Vitus (Christiansen 1984: 844).

On the basis of the above, it appears that the entire story by Helmold and repeated by Saxo is regarded widely by modern historians as fictitious, not only because of the contradictory time frame, but also as being a much later attempt by Corvey monks to make an ecclesiastic claim of archbishopric of Hamburg-Bremen to Rügen Island. Indeed, a charter to this respect was fabricated around the year 1114, in the times of Emperor's Lothar III's expedition against the Ranove of Rügen. The evidently forged Charter supposedly was issued by East Frankish king Lothair I in 844 (Christiansen 1984: 715). After they cited both Helmold's and Saxo's accounts, the authors stated: Modern scholars rejected this version of the story regarding the origins of Sventovit's cult, because of evidentiary inconsistencies and its anachronistic character. Neither Louis I nor Louis II, to say nothing about Charlemagne, ever conquered Rugen Island. The monks of Corvey[...] likely fabricated the story (Kalik \& Uchitel 2018: 53- 54). This implies that they too accept that Helmold's and Saxo's accounts in this respect are not true.

Moreover, the political situation in the region does not begin to suggest any serious penetration of the empire and Christianity in the course of the $9^{\text {th }}$ and first half of the $10^{\text {th }}$ centuries. During the $9^{\text {th }}$ century, the Carolingian Empire did not really penetrate Polabian Slavs' territories. From time to time, the Sorbs and Veletians from the Brandenburg region only nominally accepted Imperial authority and occasionally paid a tribute. The heathen 
Slavonic Obodrites were often allied with Charlemagne, first against the heathen Saxons and later against the heathen Danes. The Ranove of Rügen at that time were well beyond the reach of Empire and even more beyond the reach of Christianity (Zaroff 1996; Zaroff 2000). It should be also noted here that a monk, Ansgar, who later became archbishop of Hamburg-Bremen, underwent a mission to Denmark and later to Sweden between 826 and 831, which was described in Vita Ansgari by Rimbert, an archbishop of Hamburg and Bremen between 865 and 888. We read there: The Pope confirmed this, not only by an authoritative decree, but also by the gift of the pallium, in accordance with the custom of his predecessors, and he appointed him as his legate for the time being amongst all the neighbouring races of the Swedes and Danes, also the Slavs and the other races that inhabited the regions of the north (Rimbert XIII). However, the Vita is a classical hagiography, and its claims of a successful mission and the conversion of many Danes and Swedes seem to be a gross exaggeration. Overall, the mission was a failure, as both the Danes and Swedes remained pagan for more than the following century, and there is no evidence that Christianity took a serious foothold there as a result of Ansgar's mission. As for any Slavs, the Vita mentioned them sporadically with no indication about any real conversion success (Rimbert VI-XXXIX; Robinson 1921: 12-16; Hardt 2010: 345-354). The first bishoprics on Polabian Slavic territories were found at Brandenburg and Havelberg (Sorbian-Veletian borderlands) in 948 (Labuda, 1960: III. 183; Hardt 2010: 345-354), and in the North, on Obodrite territory at Oldenburg in 968 (Hardt, 2010: 345-354; Zaroff 1996: 102-103.

Kalik and Uchitel do not question the etymology of the root-stem *svetb, as presented at the beginning of the paper. However, they questioned that of root-stem vit. They argued that: this word is not found in any Slavic language, and is reconstructed solely on the basis of divine and personal names containing this component (Kalik \& Uchitel, 2018: 54). Indeed, it is the case, but the reconstruction of this word from witiaź/vitędzb and its abbreviated form vit, as argued the above, was researched and reconstructed by a great many scholars and accepted by most historians. The authors themselves acknowledged that an overwhelming majority of the scholars accept the root-stem vitb as meaning a lord (Kalik \& Uchitel 2018: 54). We have already explored a frequent occurrence of root-stem vitb in multiple, very common personal and geographical names across the entire Slavdom. The term logically fits the reconstruction as lord/master much more convincingly than other investigations, such as that presented in the section discussing Łuczyński's paper. We will re-visit this issue later.

Following this, Kalik and Uchitel repeated a claim that the Sventovit cult was a corrupted form of veneration of Saint Vitus, this time, approaching the issue from a different perspective. At the same time, they stated that they disregarded the accounts of Helmold and Saxo concerning Sventovit and Saint Vitus; it still needs some consideration, which contradicts their previous acknowledgement that they were not true. The revised argument went as follows. The Ranove assisted Emperor Otto I in conflict with other Slavs, namely the Obodrites, and participated in the Battle of Recknitz (TM, II.12; Widukind, III. 54-55). The authors claimed that the Ranove sided with Otto I, as they were afraid of a Danish threat and needed imperial assistance against them. On that occasion, they also 
accepted Christianity, albeit nominally. This was followed by the transfer of the Saint Vitus cult to the Rugian principality, as it was popular in parts of the empire due to a transfer of Saint Vitus relics to the Corvey Abbey in 836. When a great Slavic rebellion of the Obodrites and Veletians took place in 983, the Slavs relinquished not only imperial supremacy but also reverted to heathenism (Kalik \& Uchitel 2018: 54).

A fundamental problem with this claim is that no contemporary sources mention such a conversion of the Ranove prior to the fall of Arkona in 1168/69. Any conversion of pagans in the region was always highlighted by annalists and chroniclers, even if it was only nominal or such people relapsed shortly after. The authors do not provide any explanation why Annales Corbeienses, Annales Hildesheimenses, and all the other contemporary annals are silent about this alleged event. An argument used by authors that Widukind of Corvey, who had written his Gesta between 962 and 973 and during the reign of Otto I, did not mention the conversion of the Ranove simply because he was not interested in Rugen Island (Kalik \& Uchitel 2018: 54) does not deserve a comment. However, to clarify this, Widukind was a Saxon of noble birth; he lived and worked at Corvey Abbey and would not miss an opportunity to praise his "beloved" Otto I's achievement in the Christianization of another "bunch" of pagans and uplift the standing of his own Abbey who piously venerated Saint Vitus. Neither can he be accused of ignorance or lack of interest in Imperial, Saxon and regional affairs. Similarly, another contemporary chronicler, Thietmar of Merseburg, is regarded as a relatively reliable source. He was born in the upper-class family of count Siegfried of Walbeck. He received his education at St. John's monastery at Magdeburg and, like Helmold of Bosau, he spoke Slavic. He was consecrated bishop of Merseburg in 1009. His Chronicon, a chronicle of the Saxon dynasty's deeds, was written between 1012 and 1018 (Jedlicki 1953: XIII-XXXV, L-LII). Thus, Thietmar was well informed about Slavonic affairs and provided a long description of the Veletian cult centre devoted to the god Svarozhits (TM, VI. 23-24). It is indicative that Thietmar wrote in detail about the transfer of Saint Vitus relics to Corvey, but in Chronicon he mentioned nothing about the Christianization of the Ranove of Rügen Island and the cult of Saint Vitus there (TM, VII. 13, 53).

Furthermore, another chronicler, Adam of Bremen, an author of Gesta Hammaburgensis Ecclasiae Pontificum, who was a member of the cathedral chapter at the archbishopric of Hamburg-Bremen is noteworthy. He was born in the first half of the $11^{\text {th }}$ century in southern Germany, probably somewhere around Würtzburg. He came to Saxony and Bremen in the mid-1060s. His chronicle was written in the 1070s-1080s. Adam knew King Sven of Denmark personally, and some of his information came from the monarch. Adams knowledge of Saxon and Danish affairs seems to have extended to the geography and the people of the region (Tschan 1959: XIII-XXIII; AoB, II.XVI(14)-II.XXII(19)), and he mentions Rugiani - the Ranove of Rügen (AoB, XXII(19)). Here again, in Adam's Gesta, we find nothing supporting the alleged claim. It should be noted that the first bishops for Danes were consecrated only in 948 (AoB, II.IV). He explicitly and clearly says that the archbishopric of Magdeburg founded in 968 would have had ecclesiastic jurisdiction over the Slavic people as far as the Peene River and that it divided the archdioceses of Hamburg-Bremen and Magdeburg, but saying nothing about Rügen 
Islands, the Ranove or Saint Vitus (AoB, II.XVI(14)-XVII(15)). Finally, he provides a relatively comprehensive description of the Ranove of Rügen Island, describing their pagan beliefs, customs, military power and regional importance, and their piracy. Here, it is yet another instance in which Adam of Bremen in his Gesta makes no mention of early Christianization or Saint Vitus (AoB, IV.XVIII).

Thus, it appears that all the contemporary sources are silent on this matter, simply because such a conversion did not take place. At the risk of repetition, the first bishopric in the north on Polabian Obodrite territory was founded in 968 and lasted until the Great Slavic rebellion in 983 - a mere 15 years.

Moreover, Kalik's and Uchitel's treaties misunderstood the political situation in the region around 955 . In the middle of the $10^{\text {th }}$ century, the Ranove did not need to ally themselves with the Empire against the Danes, as they were not a threat to each other, and they were not in conflict. There is no evidence for such a conflict in Scandinavian or German sources. At best, the Danes could trade with the Ranove, and may have made sporadic raids against each other if circumstances allowed. This was a usual occurrence in the Baltic basin of that time. As for heathen Denmark, it was in the process of state formation and unification of Jutland by Gorm the Old who reigned between 936 and 958, and the Danes were not in a position to expand beyond Scandinavia (Collins 1991: 333-334; Christiansen 2006: 87-100). With the encroaching Empire and Christianity from the south, Gorm the Old would likely have preferred to be an ally not an enemy of the Ranove. As it happened, the alliance of the Ranove with Otto I was against the Slavic Obodrites. The Obodrite principality bordered mainland territories under the control of the Ranove. The contested territories were roughly between the modern city of Rostock and Ribnitz-Damgarten in Germany. As a result, the Ranove's involvement in 955 in the Battle of Recknitz was prompted by the fact that they saw the Obodrites as a threat to their interests and competitors in the region (Zaroff 2000: 7, 28-31). There was no need for the heathen Ranove to accept Christianity and, as was recorded in the sources, they came to assist the Imperial forces on their own accord. As it happened, it was the Ranove who saved the day at the Battle of Recknitz as they built a bridge across the River Recknitz, which allowed German forces under Gero to escape from their entrapment in the bend of the river and attack unsuspecting Obodrites from behind (Widukind, III. 54-55). As the evidence indicates, Kalik's and Uchitel's claim are indeed devoid of any evidence for the Christianization of the Ranove around 955. Moreover, their research and interpretation of the 955 events lack depth.

At this point, it is useful to return to the attempt by the authors to derive the root-stem of -vit in Sventovit's name from Saint Vitus. There are a number of serious problems with this interpretation. Firstly, there is an overwhelming body of evidence that the root-stem vit in Slavic names was very common and widely spread across the entire Slavdom; it cannot be linked with Saint Vitus. The root-stem -vit was a widespread element in Slavic personal names such as Dobrovit, Drogovit, Gościwit, Ljudevit, Siemowit, Witomysł, Witosław, and many others, long before the Christianization of the Slavs. Another example is Dragovit (Dragawit), a Veletian (Wiltzi) "prince", most likely of Brandenburg/ Branibor, who was defeated by the Franks and allied with the Slavic Obodrites in 789 
(Einhardi, 789). In Poland, personal names with the root-stem -vitz appear in numerous mediaeval documents. To cite a few: Siemowit (Semovith) from the chronicler Gallus Anonymous, in the early $12^{\text {th }}$ century, who refers to the Polanie's ruler/chieftain of the late $9^{\text {th }}$ or early $10^{\text {th }}$ centuries (Gallus Anonymus, III). A document titled Ex commisso nobis known as the Bull of Gniezno issued by Pope Innocent II in 1136 list a number of people with such a names. The list includes such names like Miłowit (Milovit), Radowit (Radovit), Siedlewit (Sedlevit), Snowit (Snovid), Witosza (Vitossa), Witosz (Vitos), Wniewit (Vnevit) and Snowit (Snovid) (Bull of Gniezno of 1136). There is also a person called Sdevit recorded in 1285 (Jacobus Archiepiscopus Gneznens. 1285). Another old Slavic name, Uniewit, was attested in $13^{\text {th }}$-century sources, comprising the root-stem unijb-, meaning better and -vitb (S. Urbańczyk 1977: 265). Besides, there were many people in the sources recorded as Vitus. It is not relevant here to argue whether they bore a Latin name Vitus, or were their names a Latinization of Slavonic names containing the root-stem -vitb. By numbers alone, if not most, some of them must have been Latinization of Slavonic names. The root-stem -vitb also appears in number of aforementioned place names, such as the Vitosha Mountains in Bulgaria, Wittow Peninsula, and Witt settlement on Rügen Island. In my considered opinion, there is no further need to cite further examples in this short paper.

The authors did not overlook other Slavonic deities with ending suffix -vit. They stated: [...] it can be observed that the Slavic theonyms with a-vit component (Sventovit, Rugevit, Porevit and Gerovit) were restricted to a tribal territory of the Rani (including the town of Wolgast on the mainland, were Gerovit was worshipped (Kalik \& Uchitel 2018: 54). It should be noted that the above passage contradicts their claim of Sventovit being a corrupted, grotesque incarnation of Saint Vitus. Rugevit or Rujevit was a deity worshipped at Gartz (Karenica) on Rügen Island with a large statue with seven faces and seven swords. If we accept our interpretation, it meant "Lord of Rugia". It was an older tribal deity of the Ranove, purely a tribal god, who was overtaken in importance by the supra-tribal Sventovit (Słupecki 1994: 49). This issue will be addressed later. The Saint Vitus interpretation of the Sventovit origin, proposed by Kalik and Uchitel, would produce a truly odd conclusion. The name Rugevit/Rujevit would then mean a "Rugian Saint Vitus".

Moreover, a statue of Porevit that had five heads also stood at Gartz. This deity's function and etymology is unclear and a matter of dispute. In literal terms, whatever the case may be, it was not a "Something... Saint Vitus". Finally, there was Gerovit, which most authorities read as Yarovit, and the latter form will be used here. The name Yarovit derives from Slavic jarb denoting vitality, strength, might, power, and is a cognate to the noun svętb. Following Kalik's and Uchitel's interpretation and their consequent paradigm, it would have meant or translated as a "Strong, full of vitality Saint Vitus". In all three instances, it would sound and mean an absurdity.

Furthermore, the above cited passage needs more attention. The deity known as Yarovit was indeed worshipped at Wolgast, a Baltic commercial centre (Ebbo III.8; Herbord III.6). The problem is that Wolgast was never subjugated by the Ranove of Rügen. An independent Wolgast controlled a small surrounding area and was likely to have been 
allied with the Veletian Union and, in later times, became subject to Pomeranian dukes (Zaroff 2000: 38). Not to mention, the authors omitted that Yarovit was also worshipped at Havelberg (Ebbo III.3), which is located far inland on the Havel River, in Saxony-Anhalt Land of Germany, a long way from Rügen Island. In the Middle Ages the area was inhabited by the Polabian Slavic people and is usually associated with Veletian tribes.

The authors also assumed a foreign origin of Sventovit based on other grounds. They articulated it with a vague statement that there is no earlier mention of the Sventovit cult, or other Rugian deities prior to the $10^{\text {th }}$ century and that its elaborated form was unusual among the pagan Slavs (Kalik \& Uchitel 2018: 54). It has to be agreed here that this was partially a case as the cult of Sventovit at Arkona on Rügen Island was the most complex and developed pre-Christian Slavonic cult. However, by stating so, the authors have repeatedly overlooked a number of fundamental issues. Above all, any religion is a "living" social phenomenon that undergoes slow but constant changes over time and responds to internal as well as external changes, pressures, and influences. It is noteworthy here the view of Emil Durkheim, the esteemed social and religious theorist, that religion mirrors the society that practices it (Durkheim 1968). The social and political functions of religion reflect the complexity of a society. As small tribal societies, the early Slavs of the Migration Period worshipped various Slavic deities and, in the course of time, various exclusively tribal gods emerged. At the same time, their cults were not very complex and elaborate. During and after the Slavic Migration period, beliefs and cults also diversified, albeit evolving from a common set of Slavic beliefs. In the process, different deities became the main tribal gods. When more complex political, supra-tribal entities appeared, those big tribal gods acquired or absorbed some of the other deity's functions and characteristics, turning into conglomerate of ideas, functions, etc. Consequently, they became supra-tribal syncretic gods (Rosik, 2000: 116, 120, 130-131, 293; Zaroff 2000: 100-147). For example, Perun, originally an atmospheric deity, became a war-like god among the Eastern Slavs, while a military function was incorporated into the cult of Svarozhits among the Veletians - a deity that originally was associated with fire (Zaroff 2000: 126-139).

In the case of Sventovit, as described in detail in my publication of 2002, this god from Arkona on Rügen evolved from a Yarilo-like divine being. Initially. it was a Slavic Spring deity, one of vitality, fertility. and renewal of nature. Over the course of time, under new circumstances, in new environments and after encountering the Danes and Saxons, the cult and deity evolved into Yarovit of Wolgast and Havelberg. As it stated before, the terms jarb and svęt denote the same characteristics and attributes. In the case of Ranove's Sventovit, at some stage, the root-stem jarb must have been replaced by the cognate svętı (Niederle, 1916: 142n; Brückner 1985A: 46, 128, 247; Stupecki 1994: 49; Strzelczyk 1998: 84). It should be noted, that over the course of time, as a result of frequent conflicts with the Danes and Saxons, and later with the Holy Roman Empire, the Polabian Slavs also incorporated war-like attributes into the cults of Yarovit and Sventovit (Zaroff 2002: 126-139).

The issue of complexity and elaboration of the Sventovit cult has two facets. Firstly, the Ranove created a medieval state-like principality that incorporated not only the 
inhabitants of Rügen Island, but also a large number of other mainland Slavs. At some stage, a tribal cult needed to become one that encompasses more than a single tribe and was an instrument of internal political, social and cultural consolidation and unification. This topic was comprehensively addressed by Przemysław Urbańczyk (Urbańczyk, 1995: 168-173). It is noteworthy that Helmold's account itself, in his description of Arkona and the cult of Sventovit, confirms a supra-tribal and multi-functional role of the cult and its recognition beyond the principality of the Ranove (Helmold, II.108).

This was not an isolated case. To cite a few examples, Vladimir of Kiev in the 980s created and encouraged the cult of Perun as a part of unification and state-building measures (Zaroff 1999: 47-48). Similarly, among the Polabian Slavs, the Veletian Union tried to unify the tribal confederation around a supra-tribal cult of Svarozhits, at Radegost in modern Brandenburg Land in Germany, between the $10^{\text {th }}$ and $12^{\text {th }}$ centuries (Sułowski 1981: 155-166; Żołądź 1981: 217-222). Outside Slavdom, there was an attempt by the Lithuanian Grand Duke Mindaugas, who promoted the cult of Perkūnas at Vilnius as a state religion in the mid-13 ${ }^{\text {th }}$ century (Gimbutas 1963: 202; Puhvel 1974: 78, 83). There were numerous similar developments that occurred across the known world.

Secondly, the alleged Christian influence on the cult of Sventovit is a subtle matter that cannot be answered in a single simplified statement. Those who are familiar with Saxo's description of cult and rituals at Arkona, and with some knowledge of the Pre-Christian Slavic beliefs, can recognize that there are no direct borrowings from Christianity and all of them derived from a common Slavic tradition. In contrast, there is no doubt that in some respects it was modelled on Christian worship. They developed a state-oriented cult on the Christian example of elaborate rites and temples. It was an attempt to match the challenges of the new sophisticated religion of outsiders, backed by the political and military might of the Holy Roman Empire. The ancient Slavs worshipped their gods in the open, often in holy groves, in the same way the ancient Germanic and Celtic people did (Słupecki 1994: 125-126). The concept of temples, which was more or less unique to the Polabian Slavs, was no doubt a response to Christianity and ideologically modelled on Christian churches. Moreover, there was the emergence of a clearly defined priesthood at Arkona on Rügen, in Wolgast, Brandenburg, Havelberg, Szczecin (Ger. Sttetin) and Wolin to name but few. It was a response to notable influential, well-organised, and distinguished Christian clergy (Słupecki 1994: 125-126: Rosik 2000: 309). Due to close contacts with Scandinavians, and especially the Danes, some heathen Nordic elements would likely to be found in the Northern Polabian Pre-Christian religion, but this is beyond the scope of this paper.

Concluding this section, the notion that Sventovit had nothing to do with Saint Vitus was and is supported by such scholars as again Aleksander Brückner (Brückner 1985B:36), Lubor Niederle (Niederle 1916: 142), Roman Jakobson (Jakobson 1985, ed: 7, Stanisław Urbańczyk (S. Urbańczyk 1947: 34-35), Rajko Nahtigal (Nahtigal 1956: 1-3), Leszek Moszyński (Moszyński 1975: 591), Aleksander Gieysztor (Gieysztor 1982: 90-92), Eric Christiansen (Christiansen 1984: 715), Jerzy Strzelczyk (Strzelczyk 1998: 210), Ken Dowden (Dowden 2000: 215), Stanislaw Rosik (Rosik 2000: 238-248) and Andrzej Szyjewski (Szyjewski 2003: 116) among others. Neither did any of the Russian 
followers of the Tartu-Moscow Semiotic School who proposed a different etymology for the name Sventovit ever question a Slavic origin of the name (Trubachev, 2003: 418-420; Toporov 2014: 339; Rybakov 1981: 300). Neither did Henryk Łowmiański, who only accepted a probability of later veneration of Saint Vitus among some Slavs due to the similarity of the name to Sventovit, and other deities whose names also ended with the suffix -vit as well as the root-stem being also common in many Slavic names (Łowmiański 1986: 190-192).

It should be acknowledged and understood that Kalik's and Uchitel's book is a publication which is general in nature as it deals with many Slavonic deities and many aspects of their Pre-Christian religion. However, the interpretation proposed by Kalik, and Uchitel concerning Slavic god Sventovit is highly doubtful, extremely hypothetical and not supported by any reasonable evidence. It lacks a depth of research into sources and literature on the subject. Consequently, their argument is unconvincing and seems to be based on incorrect premises. The notion of Sventovit being a corrupted form of the Saint Vitus cult was once postulated by Franz Miklosich (Miklosich 1886: 393), and never gained much support among historians. Shortly after, it has been rebuked in the early $20^{\text {th }}$ century in a comprehensive analysis by renowned Czech Slavist and historian, Lubor Niederle (Niederle 1916: 140-143). In summation, Kalik's and Uchitel's hypothesis, at least in this instance, gives an impression of some sort of a historical "excavation".

\section{ACKNOWLEDGEMENT}

I would like to express my sincere gratitude and thanks to Dr Tadeusz Cichon (PhD. Political Science \& History, University of Tasmania, Hobart, Australia) for substantial linguistic assistance and editing of the following work.

\section{ABREVIATIONS}

AoB - Adam of Bremen, Gesta Hammaburgensis Ecclesiae Pontificum

ARF - Annales regni Francorum

DLW- Digital Library of Wielkopolska

Helmold - Helmold of Bossau, Cronica Slavorum

OCS - Old Church Slavonic (Old Slavonic)

Pol. - Polish

Rimbert - Rimbert's Vita Ansgari

Rus. - Russian

Saxo - Saxo Grammaticus, Danorum Regum Heroumque Historia

TM - Thietmar of Merseburg, Chronicon

Widukind - Widukind of Corvey, Res Gestae Saxonicae 


\section{BIBLIOGRAPHY}

\section{SOURCES}

Adam of Bremen, 1959: Gesta Hammaburgensis Ecclesiae Pontificum, in F. J. Tschan (ed.), History of the Archbishopric of Hamburg-Bremen. New York: Columbia University Press.

Annales Fuldenses, Monumenta Germaniae Historica, Scriptores in Folio SS 3, Annales, chronica et historie aevi Saxonici.

Annales regni Francorum, Monumenta Germaniae Historica, Annales regni Francorum, inde Ab A.741. usque ad A. 829; qui dicuntur Annales Laurissenses Maiores et Einhardi.

Bull of Celestine III (Celestinus Pp. III 1193 Apr. 8), in Digital Library of Wielkopolska. http:// www.wbc.poznan.pl/dlibra/publication?id=12456\&from=\&dirids=1\&tab=1\&lp=1\&QI=CA632244C8297542D35E311C93BEACF8-16. Document Nr. 31 (25.10.2018).

Bull of Gniezno of 1136 (Ex commisso nobis), in Digital Library of Wielkopolska. http://www.wbc. poznan.pl/dlibra/publication?id=12456\&from $=\&$ dirids $=1 \&$ tab $=1 \& l p=1 \& Q \mathrm{I}=\mathrm{CA} 632244 \mathrm{C}$ 8297542D35E311C93BEACF8-16. Document Nr. 7 (25.10.2018).

Conradus dux Lanchicie 1247 s. d. et l.; roborat donationem cuiusdam praedii, quod Andreas clericus ecclesiae Gneznensi donaverat, Digital Library of Wielkopolska. http://www.wbc. poznan.pl/dlibra/publication?id=12456\&from $=\&$ dirids $=1 \&$ tab $=1 \& l \mathrm{p}=1 \& \mathrm{QI}=\mathrm{CA} 632244 \mathrm{C}-$ 8297542D35E311C93BEACF8-16. Document Nr. 267 (25.10.2018).

Ebbo, 1974: Vita Ottonis Episcopi Babenbergensis. Monumenta Poloniae Historica, Series II, vol. VII, part 3. Warszawa: PWN.

Fr. Michael abbas in Paradiso 1247 Mart. 3, in domo Paradisi, in Digital Library of Wielkopolska. http://www.wbc.poznan.pl/dlibra/publication?id=12456\& from=\&dirids $=1 \&$ tab $=1 \& l p=1 \&-$ $\mathrm{QI}=\mathrm{CA} 632244 \mathrm{C} 8297542 \mathrm{D} 35 \mathrm{E} 311 \mathrm{C} 93 \mathrm{BEACF} 8-16$. Document Nr. 259 (25.10.2018).

Gallus Anonymus, 1864: Gesta principum Polonorum (Chronicon), in Monumenta Poloniae Historica, Vol. 1. Lwów, 379-484.

Helmold of Bosau, 1966: Chronica Slavorum, in F. J. Tschan (ed.), The Chronicle of the Slavs. New York: Octagon Books Inc.

Herbord, 1974: Dialogus de Vita Sancti Ottonis Episcopi Babenbergensis. Monumenta Poloniae Historica, Series II, vol VII, part 3. Warszawa: PWN.

Jacobus archiepiscopus Gneznens. 1285 Jan. 17, apud Lanchiciam, in Digital Library of Wielkopolska. $\mathrm{http}: / /$ www.wbc.poznan.pl/dlibra/publication?id=12456\&from=\&dirids=1\&tab=1\&lp=1\&$\mathrm{QI}=\mathrm{CA} 632244 C 8297542 D 35 E 311 C 93 B E A C F 8-16$. Document Nr. 616 (25.10.2018).

Knytlinga Saga, 1829: in Jomsvikinga Saga og Knytlinga, København: Andreas Seidelin.

Knytlinga Saga, 1986: in H. Palson \& P. Edwards, trans, Knytlinga Saga: The History of the Kings of Denmark, Odense: Odense University Press.

Mesco dux Polonie 1103 (sic) s. d. et 1.; confirmat privilegium quod dederat monasterio de Mogilno: Salomea ducissa Polonie s. a. d. et 1. (1143?) et per illud possessionem villae Stary Radziejów cum pertinentiis, in Digital Library of Wielkopolska. http://www.wbc. poznan.pl/dlibra/publication?id $=12456 \&$ from $=\&$ dirids $=1 \&$ tab $=1 \& l p=1 \& Q \mathrm{I}=\mathrm{CA} 632244 \mathrm{C}-$ 8297542D35E311C93BEACF8-16. Document Nr. 33 (25.10.2018).

Rimbert, Vita Ansgari (Medieval Source Book). https://sourcebooks.fordham.edu/basis/anskar. asp (06.07.1999).

Saxo Grammaticus, 1984: Danorum Regum Heroumque Historia, Liber X- XVI, in E. Christiansen, (ed.). Oxford: British Archaeological Reports, International Series No. 84. 
Thietmar of Merseburg, 1953: Chronicon, in M. Z. Jedlicki (ed.), Kronika Tietmara. Poznań: UAM. Widukind of Corvey, 2015: Res Gestae Saxonicae. G. K. Wałkowski, trans., Widukind: Dzieje Sasów. Bydgoszcz: Euro OMNI.

\section{Publications}

Balg, G. H. A., 1887-1889: Comparative Glossary of the Gothic Language with Especial Reference to English and German. New York: Westemann \& Co.

Boryś, W., 2006. Stownik etymologiczny języka polskiego. Kraków: Wydawnictwo Literackie.

Brückner, A., ed., 1985A: Mitologia stowiańska i polska. Warszawa: Państwowe Wydawnictwo Naukowe.

Brückner, A., ed., 1985B: Stownik Etymologiczny Języka Polskiego. Warszawa.

Christiansen, E., 1984: Danorum Regum Heroumque Historia, Books XIV - XVI Notes. E. Christiansen (ed.), Saxo Grammaticus. Oxford: British Archaeological Reports, International Series No. 84.

Christiansen, E., 2006: The Norsemen in the Viking Age. Oxford: Blackwell Publishing.

Collins, R., 1991: Early Medieval Europe. London: MacMillan Education Ltd.

Dowden, K., 2000: European Paganism: The Realities of the Cult from Antiquity to the Middle Ages. London: Routledge.

Durkheim, E., 1968: The Elementary Forms of the Religious Life. London: George Allen \& Unwin Ltd.

Ганина, Н. А., 2015: Тайны рюгенских сллавян. Studia Slavica et Balcanica Petropolitana, No. 2, 65-81.

[Ganina, N. A., 2015: Tainy rugenskikh slavyan. Studia Slavica et Balcanica Petropolitana, No. 2, 65-81.]

Gieysztor, A., 1982: Mitologia Stowiańska. Warszawa: Wydawnictwo Artystyczno Filmowe.

Gimbutas, M., 1963: The Balts. London: Thames \& Hudson.

Gołą, Z., 1992: The origin of the Slavs: A Linguist's View. Columbus: Slavica Publishers Co.

Hardt, M., 2010: Structures of power and religion according to the written sources. Trade and Communication Networks of the First Millennium AD in the northern part of Central Europe: Central Places, Beach Markets, Landing Places and Trading Centres. Hannover: Niedersächsisches Landesmuseum, 345-354.

Hrynkiewicz-Adamskich, B., 2011: Słowiańskie imiona osobowe - voces magicae? Onomastica Slavogermanica, XXX, Wrocław, 177-196.

Jakobson, R. (ed.), 1985: Selected Writings, Vol. VII. New York: Mouton Publishers.

Kalik, J., \& Uchitel, A., 2018: Slavic Gods and Heroes. London, New York: Routledge.

Labuda, G., 1960. Fragmenty dziejów słowiańszczyzny zachodniej, Vol. 2. Poznań: UAM.

Łowmiański, H., 1986. Religia słowian i jej upadek. Warszawa: Państwowe Wydawnictwo Naukowe.

Łuczyński, M., 2015: Staropołabskie teonimy teonimy *Svętovitъ, *Jarovitъ, *Rujevitъ,

*Borovitъ: deadiectiva czy composita? Ling Varia, X (2015)/2(20), 109-120.

Miklosich, F., 1986: Etymologisches Wórterbuch der Slavischen Sprachen. Wien: Wilhelm

Braumüller.

Moszyński, L., 1975: Stownik Starożytności Stowiańskich, Vol. V. Wrocław: Ossolineum.

Nahtigal, R., 1956: Svętovit. Slavistična revija, Vol. IX, 1-9. 
Niederle, L., 1916: Slovanské Starožitnosti, Odil Kulturni, Život Starých Slovanů, Dil II. Praha: Bursik \& Kohout.

Osięgłowski, J., 1971. Wyspa słowiańskich bogów. Warszawa: Książka i Wiedza.

Puhvel, J., 1974: Indo- European Structure of the Baltic Pantheon. G. J. Larson (ed.), Myth In Indo-European Antiquity. Berkeley: University of California Press, 75-86.

Robinson, C. H., 1921: Introduction to Series. Rimbert: Life of Anskar, the Apostle of the North 801865 (Medieval Source Book) https://sourcebooks.fordham.edu/basis/anskar.asp (06.07.1999)

Rosik, S., 2000: Interpretacja chrześsijańska religii pogańskich Stowian w świetle kronik niemieckich XI - XII wieku. Wrocław: Wydawnictwo Uniwersytetu Wrocławskiego.

Рыбаков Б. А., 1981: Язычество древних славян. Москва: Издательство "Наука". [Rybakov, B. A., 1981: Yazichestvo drevnikh slavyan. Moscow: Izdatelstvo "Nauka".]

Skeat, W. W., 1868: A Meso-Gothic Glossary and Grammar. London: Asher \& Co.

Stownik Starożytności Stowiańskich, Vol. I-VIII. 1961-1994. Wrocław: Ossolineum.

Słupecki, L. P., 1994: Pagan Slavonic Sanctuaries. Warszawa: IAE.

Strzelczyk, J., 1998: Mity podania i wierzenia dawnych Stowian. Poznań: Dom Wydawniczy REBIS.

Sułowski, Z., 1981: Sporne problemy dziejów Związku Wieletów-Luciców”. J. Strzelczyk,

Słowiańszczyzna Połabska. Poznań: Wydawnictwo Uniwersytetu im. A. Mickiewicza, 155-166.

Szyjewski, A., 2003: Religia Stowian. Kraków: Wydawnictwo WAM.

Топоров, В. Н., 2014: Мифология: Стати для мифологических энциклопедий, Том 2. Москва: ЯСК.

[Toporov, V. N., 2014: Mifologiya: Stati dlya mifologicheskikh entsiklopedii, Tom 2. Moscow: YaSK.

Трубачев, О. Н., 2003: Этногенез и культура древнейших славян. Лингвистические исследованния. Москва: Издательство "Наука".

[Trubachev, O. N., 2003: Etnogenez i kultura drevneyshikh slavyan. Lingvisticheskiye issledovaniya. Moscow: Izdatelstvo "Nauka".]

Трубачев, О. Н., Мысли о дохристианской религии славян в свете славянского языкознания. Труды по этимологии. Слово. История. Культура, Том 2. Москва: Издательство “ЯСК”.

[Trubachev. O. N., 2004: Mysli o dokhristianskoy religii slavyan v svietye slavyanskogo yazikoznaniya. Trudy po etimologii. Slovo. Istoriya. Kultura. Tom 2. Moscow: Izdatelstvo "YaSK".

Tschan, F. J., 1959: Adam of Bremen's, Gesta Hammaburgensis Ecclesiae Pontificum.

F. J. Tschan (ed.), History of the Archbishopric of Hamburg-Bremen. New York.

Urbańczyk, P., 1995: Religia pogańska jako ideologia społeczeństw plemiennych. Światowit,

Vol. 40, 168-173.

Urbańczyk, S., 1947: Religia pogańskich słowian. Kraków: Wydawnictwo Studiów Słowiańskich Uniwesytetu Jagielońskiego.

Urbańczyk, S., 1977: Słownik Starożytności Słowiańskich, Vol. VI. Wrocław: Ossolineum.

Vasmer, M. (ed.), 1986: Руиссисчес Етимологисчес Вӧртербуч, Вол. И-ИВ. Этимологичский Словарь Русково Языка, Tom I-IV. Москва: Издательство "Прогресс".

[Vasmer, M. (ed.), 1986: Ruissisches Etimologisches Vörterbuch, Vol. I-IV. Etimologicheskii Slovar Ruskovo Yazika, Tom I-IV. Moscow: Izdatelstvo " Progress".]

Wędzki, A., 2008: Wczesna Słowiańszczyzna: Przewodnik po dziejach i literaturze przedmiotu, Vol. 1. Warszawa: Slawistyczny Osrodek Wydawniczy.

Zaroff, R., 1999: 'Organized Pagan Cult in Kievan Rus'. The Invention of Foreign Elite or 
Evolution of Local Tradition? Studia Mythologica Slavica, No. 2, 47-76.

Zaroff, R., 2000: The Origins and Evolution of the North-Eastern and Central Polabian

(Wendish) Religious and Political System. PhD thesis, The University of

Queensland. The University of Queensland's Institutional Digital Repository. http://espace.library. uq.edu.au/view/UQ:157891

Zaroff, R., 2002: The Origins of Sventovit of Rügen. Studia Mythologica Slavica, No. 5, 9-18.

Żołądź, D., 1981: Redarowie. J. Strzelczyk (ed.), Słowiańszczyzna Połabska. Poznań: Wydawnictwo Uniwersytetu im. A. Mickiewicza, 217-222.

\section{RUGIJSKI SLOVANSKI BOG SVENTOVIT - PONOVNO \\ ROMAN ZAROFF \\ $\infty$}

Avtor izpodbija interpretacijo imena Sventovit poljskega jzikoslovca Michała Łuczyńskega in sicer predvsem na podlagi primerjalnih argumentov, ter pojasnjuje, da ime rugijskega božanstva verjetno ni kombinacija korena svętz- (moč, jakost, sila) in pripone -ovitb (tisti, ki poseduje moč, jakost, silo), ki kaže na pridevniško/ svojilno lastnost in kvaliteto in nekoga, ki poseduje moč, jakost in silo, kot to navaja Łuczyński. Avtor članka se sicer strinja z etimološkim izvorom korena svętb-, a obenem predstavi svojo veliko bolj verodostojno interpretacijo, ki jo je podal že v članku iz leta 2002 (gl. Literaturo), kjer navaja, da je ime Sventovit sestavljen iz korenov svętb- ter -vitb, in ne ovitz, kjer -vitb izhaja iz slovanske besede vitędzb, ki pomeni bojevnik, vladar ali gospodar. Sventovit naj bi torej po vsej verjetnosti pomenil »mogočen in/ali močen vladar« ali sorodno pomensko zvezo.

Judith Kalik in Alexander Uchitel v knjigi Slavic Gods and Heroes (2018) navajata, da je Sventovit izkrivljena oblika imena Sveti Vid, medtem ko pričujoči članek pojasnjuje, da temu ni tako. Poglavje v omenjeni knjigi, ki zadeva Sventovita, priča o zelo površnem znanju o srednjeveških Slovanih ter pomanjkljivi analizi pričujočega verskega pojava, hkrati pa nasprotuje odkritjem številnih sodobnih raziskovalcev po vsem svetu. Avtor v tem članku pojasnjuje, da je etimološki izvor imena Sventovit zakoreninjen globoko v slovansko tradicijo, kar dokazujejo primerjalne analize številnih zgodovinskih virov in lingvističnih gradiv. Zaključuje, da je ime Sventovit v slovanskih jezikih pomenilo »mogočen in/ali močen gospodar«.

Roman Zaroff, Ph.D., 4/61 Mimosa Rd., Carnegie, Vic., 3163, Australia, r_zaroff@yahoo.com.au 